\title{
Partnership, Collaboration and Mutual Gains: evaluating context, interests and legitimacy.
}

\section{Adrian Wilkinson, Tony Dundon, Jimmy Donaghey, and Keith Townsend}

Since it emerged as a political and organisational phenomenon, supporters of the partnership approach have associated it with the potential to engender mutually beneficial relationships at the organisational level (Ackers and Payne, 1998). Alternatively, collaborative relationships have been argued to be contrary to the long-term interests of workers and trade unions, typically underpinned by notions of managerial incorporation (Kelly, 2004). Thus, over the past twenty years, the notion of workplace partnership, collaboration and associated mutual gains has resulted in very heated debates regarding employee representation and voice and the extent to which mutual gains are actually realisable (Kochan and Osterman, 1994; Holland et al, 2012). Other debates concern the concept of partnership in the absence of union recognition (Dietz et al, 2005; Johnstone et.al, 2010). Research over this time has been inconclusive with some studies revealing a range of benefits including stronger workplace organisation (Roche and Geary, 2006); Non-union Employee Representation (NER) structures premised on mutual gains (Kaufman and Taras, 2010), union survival (Ackers and Payne, 1998); informal dialogue and collaborative regime longevity (Rittau and Dundon, 2010); while other evidence points towards work intensification (Marks et al, 1998); job insecurity and limited union effectiveness (Kelly, 2004). While research is diffuse, what is apparent is that partnership depends upon various contextual factors including management and union strategies, the aims of partnership and related human resource policies, along with wider economic conditions (Dobbins and Gunnigle, 2009; Teague and Hann, 2010). The last two decades have shown that collaborative trust-building employment relationships can wither more than they succeed (Alfes et al, 2012. It is equally apparent that there is little consensus to the explanation about the waxing and waning of such collaborations and the various threads of this research agenda are likely to endure for some time (Wilkinson et al, 2014).

Many of the debates seeking to explain partnership success or failure over the past decade also approach the topic with an assessment of 'outcomes' as the holy grail, while others seek to understand the 'processes' that seek to deliver mutuality for the parties involved (Danford et.al, 2008; Jenkins, 2008; Johnstone et al, 2009; Evans et al, 2012; Samuel, 2007). The context is one in which radical changes in economic, market environments and industrial relations legislation are reshaping workplaces Higher productivity is being sought by involving employees in new work systems and regularising that involvement, but will this be more productive and successful than preexisting union-management relationships? Policymakers from both sides of politics have envisaged productivity gains from major changes to industrial relations legislation that have been enacted or foreshadowed. Throughout the world governments periodically wheel out a new (or recycled) agenda and discourse around developing more cooperative and less adversarial industrial relations. (Wilkinson et al 2010; Wilkinson et al, 2014) Recent scholarly and practitioner debates point towards the need to develop long-term tests for genuine mutuality as a sustainable source of employee engagement, organisational effectiveness as well as contributing to job quality (Boxall, 2013). 
Stuart and Martinez Lucio (2000) argue strategic partnership is not just about outcomes, or its potential for trade unions. Rather, partnership is a development that represents the emergence of a new approach to employment relations that attempts to reconfigure the form and content of management-union relations. It raises broader questions about the regulation of employment relations, the way practices and processes are played out and by whom, and not just its outcomes. Recent discourses have been based on a new approach to managing employment which balances efficiency concerns with that of employee entitlements and fairness. However, there are important gaps in our knowledge of how successful relationships between employees, their representatives and managers are conducted and being developed for the future, knowledge which we need if we are to plot a new path in employment relations.

\section{The context of partnership, collaboration and mutual gains}

In the United States, experiences of management-union relationships such as co-management involves similar processes of cooperation and collaboration with management and unions working together to achieve productivity outcomes. Research from North America has typically been at the forefront of claims that link innovative employee and union involvement practices to economic and productivity benefits (Freeman and Medoff, 1984; Hirsch, 2004; Krats and Brown, 2012). In industries experiencing significant competitive pressures, more positive outcomes for employees are linked to a strong union able to negotiate job security, obtain strategic positions as pension trustees, and disperse profits from increased productivity to wages from the start (Greenwald, 2004; Sayce et al, 2012). In Australia also, Price et al (2014) highlight a union case that adopted a highly collaborative approach which led to some material gains for its members. However, the facilitation and sustainability of employee representatives or union involvement requires considerable effort and dedication by management and both parties may need to be prepared to give something away before they can gain from the process.

In the United Kingdom (UK) declining unionism, pressures for organisations to be competitive, together with the European Union policy agenda of developing cooperative workplace structures (such as works councils), has produced the 'partnership alternative' for management, employees and unions (Wilkinson et al., 2007). Certainly throughout the Labour Government period (19972010) union (and to a lesser extent, non-union) partnership agreements increased in numbers in the UK and have been subject to considerable debate concerning the positive and negative outcomes for employees (Bacon and Samuel, 2009). It is suggested that to represent effectively employee interests requires a far more collaborative approach towards management than previously taken by unions (Hyman, 2002). Others see partnerships as a form of employee control and facilitating the acceptance of managerial practices (Kelly, 2004). Recent policy debates in the UK around the excesses of modern capitalism and how it fuelled the crisis has seen the Conservative-Liberal Democrat coalition extolling the virtues of the 'John Lewis economy'. In particular, the government has used this model to propose workers can trade employment rights for ownership rights. However, the Utopian picture draw of the John Lewis Partnership model is questioned by Cathcart (2014) who highlights that the "business case" discourse dominates the partnership, possibly to the detriment of other interests.

Roche and Teague (2014) highlight how the public policy agenda in Ireland failed to disseminate partnership from a (now defunct) national platform to enterprise-level practices. The national partnership framework in Ireland collapsed after over 20 years amidst the severity of economic 
austerity. Some suggest that in difficult times a partnership approach makes sense by engaging employees in tough decisions that directly affect them (Teague and Roche, 2013). The consideration of national-level variables is particularly significant, as participation is not only influenced by the strategic choices of managers and employees, but also wider societal and in particular global neo-liberal forces in which partnerships operate (Wood 2010; McDonough and Dundon, 2010). In parts of Europe (such as Germany) for instance, the government provides for participation as an employee's statutory right via the involvement of Works Councils (Budd and Zagelmeyer 2010).

A major theme running through much of the literature critical of partnership in voluntarist contexts, is that voluntary arrangements in situations of unequal power prove difficult to sustain collaborative arrangements (Freeman and Lazear, 1995; Terry, 2003a and 2003b). Despite this, partnership has been promoted as a public policy goal in liberal economies such as the US, the UK and Ireland (Osterman et al, 2002; Ackers and Payne, 1998; Dobbins and Gunnigle, 2009), and to a lesser extent, Australia (Townsend et al, 2013; Holland et al, 2012). The question is what factors sustain or hinder the enabling conditions for partnership? Throughout the literature, two main strands have been identified as enabling meaningful partnership. At the macro-level, strong public policy commitments including statutory rights have been argued to be necessary to enshrine meaningful collaborative voice. Turnbull et al (2004) highlight that in the absence of strong public policy, partnership in the voluntarist regimes of the UK-based British Airways and Irish Aer Lingus was only rhetorical, compared to that in the more legally supported German-based Lufthansa model. Brewster et al (2014) echo this finding in highlighting that the more supportive environment of coordinated market economies is more fertile ground for embedded collaboration than conditions found in liberal market economies. However, the Republic of Ireland proved an interesting case, where a national tripartite system based on corporatist principles collapsed after twenty two years (Teague and Donaghey, 2009; McDonough and Dundon, 2010; D'Art and Turner 2011;). In this case a public policy agenda sought to encourage voluntarist partnership, rather than follow a legally-protected German-style works councils system. Roche and Teague (2014) evaluate this public policy preference and argue that success was mostly limited. Contrary to Terry (2003b), they argue that the absence of a policy agenda to encourage the fostering of trust between parties, rather that strict constraining legislation, explained the disappointing uptake of partnership.

In recent times, the European Union has been to the forefront of developing legislation aimed at increasing worker involvement across the entire European Union. Legislation around areas such as collective consultation for redundancies, works councils in multinationals and transfers of undertakings have all been subject of specific EU directives requiring national implementation, with the implicit target being to raise the quality and quantity of employee participation particularly in those neo-liberal markets with fewer constraints, like the UK and Ireland. Yet, the rhetoric of the Commission has shifted in this regard. Gold (2010) traces a shift in the rationale for encouraging worker participation from one of deepening integration and harmonisation to a more business-case "productive factor" approach, culminating in Directive 2002/14/EC, commonly referred to as the Information and Consultation Directive. Cullinane et al (2014) examine the extent to which NERs created through the transposed legislation from this Directive in the UK and Ireland developed a mutual gains approach. They find that the minimalism of this legislation was generally insufficient to develop meaningful consultation around issues of mutual concern. 
Yet, it would be foolhardy to think that the macro-environment alone is sufficient to promote meaningful collaboration or that it is always necessary. Kochan and Rubenstein (2000) highlight that the stakeholder approach in the famous Saturn partnership was key to developing such a collaborative approach. They highlight that worker participation in all levels of decisions, from the choice of top leaders to more operational issues, facilitated a relatively well sustained partnership at Saturn. Brewster et al's (2014) findings are consistent with this and argue that the micro context in terms of firm strategy, sectors and the like is an additional important context for successful partnership and mutual gains. In particular they highlight that a stakeholder rather than a shareholder approach is more conducive to meaningful partnership approaches. Similarly, Whyman and Petrescu (2014) focus on the range of issues covered by partnership and argue that focusing partnership on a relatively narrow range of issues had higher perceptions of success for both employers and employees. They highlight that internally supportive factors, or 'HR bundles, also enhance the effects of partnership. Similar partnerships have also been identified as key to sustaining collaborative employment relationships leading to behavioural outcomes underpinning broder human resource performance indicators for firms (Knies and Leisink, 2013). However, Danford et al (2014), point out that in the context of professional occupational settings, partnership can lead to a weaker union role in terms of collective influence over management policy. Kinge (2014) examines the UK policy environment in the public sector, specifically the National Health Service. She argues that the top-down nature of the relationship, rather than stifling partnership, could provide the focus and support for specific problem solving activity and somewhat insulate it from external macro-factors. However, in the long run, it is argued that while institutional support is important for codifying and establishing practice, the sustainability is linked to the quality of relationship being built. Price et al (2014) highlight that the institutional nature of the Australian system, with Awards and standard minimums provided a context where a union ideologically committed to collaboration was able to foster such relationships. Yet Cathcart (2014) highlights that the devil may often in the detail of stakeholder approaches which appear to have multiple interests at their very heart, but using non-union partnership to pursue a heavily managerialist agenda. Conflicting evidence again suggests that understanding the context becomes critical in understanding the phenomena.

\section{Reconciling interests: mutual gains and pains of partnership}

Partnership is often premised on elements of earlier theories of collective bargaining and in particular the distinction between distributive and integrative bargaining developed by Walton and McKersie (1965). Distributive bargaining has the function of resolving pure conflicts of interests and aims to allocate fixed sums of resources (dividing the pie) and hence often has a 'zero-sum', or conflictual, outcome. Tactics centre on developing the negotiators relative power, convincing the other party of the first party's power and resolution, modifying the other party's expectations, closely guarding information, and preventing the other side from using the same tactics. Integrative bargaining, by contrast, aims to identify common or complementary interests and fosters a problemsolving collaboration among both parties. The aim is to work towards achieving joint gains (expanding the size of the pie) and identifying opportunities for 'win-win' outcomes. Similarly, partnership is underscored by its extent to aid in mutual problem-solving through deliberative means (Dietz, 2004; Teague, 2005). To use the deliberation analogy coined by Lucio Baccaro 
(2006) why fight over an orange if one party wants the peel and the other wants the pulp? Tactics include exchanging information, exploring underlying interests and engagement in problem solving techniques. In short, partnership is about "management and unions working together to produce a bigger pie as well as fighting over the size of their slices" (Freeman and Medoff, 1984:165). Thus, partnership is viewed as a process, rather than an outcome of its own right. Johnstone et.al (2009) proposes that a more useful definition would focus upon the practices and processes associated with partnership. One of the real tests of partnership and collaborative employment relations emerge when organisations are faced with retrenchment. Hall and Purcell (2012) highlight that in organisations which are "active consulters", organisational challenges increase the quality of consultation, whereas those with less embedded consultative cultures may move towards managerial unilateralism. On a similar note, Butler et al (2011) highlight that partnership can be a mechanism for dealing with "mutual pain" as well as mutual gain, with trust being the key mediator. Both these recent pieces highlight that the real test of meaningful engagement is often not dividing the gains but the ability of processes to steer a path through difficult times.

While the process and practices of partnership need to be separated from employment relations outcomes, a key area of research in the partnership literature has been to evaluate who has gained from the partnership process. Evans et al (2012) highlight that both the process and outcomes of partnership must be examined in order to evaluate partnership. In terms of outcomes, Guest and Peccei (2001) demonstrated that both employers and workers on the whole witnessed gains from partnership, though employers benefitted to a greater extent. Yet, gains are not simply attributable as simply being gains for workers or employers. Glover et al (2014) develop the notion of a 'hierarchy of gains for workers', identifying both hard and soft gains that may emerge from partnership working. 'Hard gains' are instrumental in helping to form the foundations for partnership and include direct material gains such as financial rewards and positive safety outcomes. If hard gains develop then workers develop confidence that partnership can deliver and may begin to place more value on soft gains such opportunities for personal growth and development and meaningful mechanisms for employee voice.

One potentially important moderator identified in the union-productivity literature is the nature of the relationship forged between management and unions as well as the overall employment relations climate. In this regard, the notion of workplace 'partnership' between management and unions resulted in distinctive and vociferous debates regarding the future of employee voice in the UK and attracted significant policy attention in the 1990s (IPA, 1997, TUC, 1999). Though the exact meaning of partnership remains contested after more than a decade of debate (Ackers et.al, 2004; Ackers and Payne, 1998; Dietz, 2004; Stuart and Martinez-Lucio, 2004), it is generally associated with an attempt to shift from adversarial to more cooperative relations between unions and management (Johnstone et.al, 2009). A central theme is the attempt to reconcile the countervailing efficiency and social pressures which characterise the employment relationship by galvanising all parties around a joint interest in the success of the enterprise (Martinez-Lucio and Stuart, 2002). Partnership aligns with the increasing recognition of the need to manage to address the several strategic tensions (Boxall and Macky, 2007) and to consider HR outcomes in terms of mutuality and sustainability in the long-term rather than just short-term economic expediencies (Guest, 2011; Boxall, 2013; Johnstone and Wilkinson 2013). 
A complexity in evaluating partnership outcomes is a lack of agreement regarding what partnership is expected to achieve, or how to set appropriate measurements for success. Consequently, outcomes are too easily offset against benchmarks which are either quite vague (e.g. increasing transparency, enhancing training and development, creating a better quality of working life), or highly ambitious such as the renaissance of the union movement as the default mechanism for employee voice (Johnstone et.al, 2010). A useful framework with which to evaluate collaborative relationships is advanced by Budd (2004). His model suggests that pluralist employment relations are about the ability to find a balance between efficiency, equity and voice. Extreme positions are seen as undesirable and, indeed, untenable. While efficiency is often the focus of policy in relation to the workplace this has to be balanced with equity defined as fair employment standards and treatment, and voice defined as meaningful input into decisions. Balance does not mean equal weighting but the search for arrangements that enhance one or more dimensions without undue sacrifices in other dimensions (Budd 2004). These can provide the dimensions for evaluating partnerships. A central assumption of this potential research agenda is that it is possible to reconcile the countervailing efficiency and social pressures which characterise the employment relationship by recognising the plurality of interests, and uniting these around the goal of a successful enterprise. It can be argued that this balance will require new forms of organisational relationships and governance processes, as well as an equitable division of the gains (Johnstone and Wilkinson, 2013). Townsend et al (2014) provide three case studies where different approaches to the collective and individual management of the employment relationship demonstrate that positive efficiency and social pressures can be achieved through various means.

\section{Partnership legitimacy: union and non-union employee representation}

Partnership and engaging in collaborative relationships has been held up as a method of achieving union revitalisation: in essence, unions proving their value in organisations will lead to a more hospitable approach from employers (Kochan and Osterman, 1994; Ackers and Payne, 1998). In the UK, the TUC invested significant resources into developing a partnership agenda. Given the decline in trade union representation, research has assessed the potential of partnership as a union revitalisation strategy. Heery (2002) argues that for individual unions, partnership and organising are not necessarily mutually exclusive. Heery outlines that different workplaces may require different strategies or that organising may be an ingredient for more balanced partnership. While partnership was advocated by some as a potential revitalisation strategy for unions in the UK (Ackers and Payne, 1998), Terry (2003a) argues that embracing partnership would first require a change in union structures and orientation, as well as a supporting legal environment. In terms of union membership, partnership has not prompted an upsurge in members and this is unsurprising given that Bacon and Samuel (2009) estimate fewer than 4 per cent of private sector workers in the UK are covered by partnership agreements. McIlroy (2008), examining TUC learning programmes as a partnership agenda is sceptical of the potential of partnership to revitalise unions. However, as Whyman and Petrescu (2014) highlight, a rather narrowly focussed agenda for partnership can be productive in developing workplace level trade unionism.

In a polemic analysis, Kelly (1999) asked how can unions be a partner with an employer, when the employer would rather you did not exist? Although unions remained the key source of employee voice representation for the majority of the $20^{\text {th }}$ century, the decrease in unionisation over recent years has seen the concept become more encompassing (Batt et al, 2002). With this, many 
employers have developed internal voice mechanisms and even capitalise on informal and specific non-union voice (Townsend et al, 2013; Marchington and Suter, 2013). As a form of voice, the partnership literature has been extended to cover both unionized and non-unionised structures (Dundon et al, 2005; Johnstone et al, 2010). Dietz et al (2005) argue that partnership must be judged not by the parties who participate in the processes but the extent to which they foster problemsolving and a mutual gains approach. Theoretically, then, partnership can be envisaged as a nonunion relationship and as such collaboration and mutuality link with the notion of voice in the workplace in the absence of a trade union, including specific NER alternatives. As Ackers et al (2004) remind us, non-union partnership and voice is wholly feasible and it remains an empirically underexplored issue as to the potential efficacy of NERs. For such an exploration, see Cullinane et al (2014).

While there is a commonly acknowledged decrease in union density throughout the world, we are also witnessing the increasing realisation that employee collectivism can be delivered in different ways. Alternative forms of employee voice that promote employee creativity and greater use of discretionary effort are important factors to consider within the collaborative approach of non-union workplaces. Non-union firms tend to use employee voice as a means of upward problem solving, with the core aim to increase performance through information sharing (Bryson et al. 2006, Dundon et al. 2005, Wilkinson et al., 2013) but are not always seen as partnership, often with employee representatives accused of being "in the pockets of management" (Watling and Snook, 2001). Cathcart (2014) argues that the lack of independent representation in John Lewis - an employee owned company led to capture of processes for organizational elites.

Partnership also links to a broader debate about unions and performance. Research suggests that there is a weak, slightly positive or slightly negative association, and that the context in which the organisation and union operate is fundamental to understanding the outcomes. Hirsch (2004) summarised that the "average union effect [on productivity] is very close to zero, and as likely to be somewhat negative as somewhat positive", however he adds that when the 'higher compensation' to employees in union companies in the US means that the profitability of union firms is lower than in non-union companies. Addison's (2005: 416) analysis of empirical findings on the unionperformance relationship found that, "on average, union effects on productivity are small." In a meta-analysis of 73 studies published between 1977 and 2002, Doucouliagos and Laroche (2003) found that, although variations occurred between nations and industries, the overall effect of unions on productivity was close to zero. Coats summarises the situation nicely by noting that "...unions can be good for productivity, bad for productivity or of no consequence at all." (Coats 2004: 35). There are a multitude of contextual variables which can influence the outcomes of unions on organisational performance. One of these is likely to be partnership. Freeman (2005) acknowledged that productivity effects associated with unions are more likely due to the interactions between unions and management, which are in turn, influenced by the particular industry and firm related variables. He further suggested that when the industrial relations environment between union and management is strained, performance levels are likely to reduce. Similarly, Townsend et al, (2014) demonstrate that in three cases, the one with strained relationships between managers and the union witnessed the lowest level of performance gains.

\section{Conclusions}


Johnstone and Wilkinson (2013) argue that the quest for labour-management partnership is potentially a form of governance which can regulate the various tensions between efficiency, equity and voice. At the same time, however, models of partnership may need to be developed for different sectors and groups of workers rather than assuming a one size fits all approach, and may also need to be integrated into a broader and supportive HR system to generate trust and achieve mutual gains across diverse workgroups (Holland et al, 2012; Alfes et al, 2012). HR and IR systems cannot operate in isolation. Furthermore, it is too simplistic either to celebrate partnership as a panacea for organizational ills, or equally to dismiss it because it has failed to transform the employment relationship or advanace the interests of unions per se. To celebrate partnership as workplace democracy challenging relations between capital and labour is to overstate its potential contribution (Wilkinson et al., 1997) and ultimately, unhelpful. Variations of what we now refer to as partnerships, collaboration, and/or mutual gains have existed as long as the employment relationship. We are now at a point in time where nuances and contexts must be explored as a means to develop theory and influence practice so those interested scholars, practitioners, and policy-makers can see "management and unions working together to produce a bigger pie as well as fighting over the size of their slices" (Freeman and Medoff, 1984:165).

\section{References:}

Ackers, P., and Payne, J. (1998), 'British trade unions and social partnership: rhetoric, reality and strategy’. International Journal of Human Resource Management, 9(3): 529-550.

Ackers, P., Marchington, M., Wilkinson A. and Dundon, T. (2004), 'Partnership and Voice, with or without Trade Unions: Changing UK management approaches to organisational participation', in M. Stuart, and M. Martinez-Lucio (Eds), Partnership and Modernization in Employment Relations, London: Routledge.

Addison, J. (2005), 'The determinants of firm performance: Unions, works councils, and employee involvement/ high performance work practices', Scottish Journal of Political Economy, 52(3): 406-450.

Alfes, K., Shantz A. and Truss, C. (2012), 'The link between perceived HRM practices, performance and well-being: the moderating effect of trust in the employer', Human Resource Management Journal, 22(4): 409-27.

Baccaro, L. (2006), 'Civil society meets the state: towards associational democracy?' SocioEconomic Review, 4(2): 185-208

Bacon, N. and Samuel, P. (2009), 'Partnership Agreement Adoption and Survival in the British Private and Public Sectors', Work, Employment and Society, 23(2): 231-248.

Batt, R., Colvin, A. J. S. and Keefe, J. (2002). 'Employee voice, human resource practices, and quit rates: Evidence from the telecommunications industry,' Industrial and Labor Relations Review, 55: 573-594.

Boxall, P. (2013), 'Mutuality in the management of human resources: assessing the quality of alignment in employment relationships, Human Resource Management Journal, 23(1): 317.

Boxall, P. and Macky, K. (2007). 'High-performance work systems and organisational performance: Bridging theory and practice', Asia Pacific Journal of Human Resources, 45(3): 261-270.

Brewster, C., Brookes, M., Johnson, P. and Wood, G. (2014), 'Direct Involvement, Partnership and Setting: A Study in Bounded Diversity', International Journal of Human Resource Management, (insert issue details) 
Bryson, A., Charlwood, A. and Forth, J. (2006), 'Worker voice, managerial response and labour productivity: an empirical investigation', Industrial Relations Journal, 37(5): 438-455.

Budd, J. W. (2004). Employment with a human face: Balancing efficiency, equity, and voice. Ithaca: Cornell University Press.

Budd, J. W. and Zagelmeyer, S. (2010). 'Public policy and employee participation', in A. Wilkinson, P. J. Gollan, M. Marchington and D. Lewin (Eds.) The Oxford Handbook of Participation in Organisations. New York: Oxford University Press.

Butler, P., Glover, L., and Tregaskis, O., (2011) 'When the Going Gets Tough: Recession and the Resilience of Workplace Partnership', British Journal of Industrial Relations, 49(4): 666687.

Cathcart A (2014), 'Paradoxes of Participation: Non-Union Workplace Partnership in John Lewis, International Journal of Human Resource Management, (insert issue details)

Coats, D. (2004). 'Speaking Up! Voice, Industrial Democracy and Organisational Performance.' London: The Work Foundation.

Cullinane, N., Donaghey, J., Dundon, T., Dobbins, T. and Hickland, E. (2014), 'Regulating for Mutual Gains? Non-Union Employee Representation and the ICE Directive', International Journal of Human Resource Management, (insert issue details)

D’Art, D., and Turner, T. (2011), 'Irish trade unions under social partnership: a Faustian bargain?', Industrial Relations Journal, 42(2): 157-173.

Danford, A., Richardson, M., Stewart, P., Tailby, S. and Upchurch, M. (2008). 'Partnership, high performance work systems and quality of working life', New Technology, Work and Employment, 23(3): 151-166.

Danford A, Durbin, S; Richardson, M; Stewart, P; Tailby, S. (2014), 'Workplace partnership and professional workers. 'About as useful as a chocolate teapot', International Journal of Human Resource Management, (insert issue details)

Dietz, G. (2004), 'Partnership and the development of trust in British workplaces', Human Resource Management Journal, 14(1): 5-24.

Dietz, G., Cullen, J. and Coad, A. (2005), 'Can there be non-union forms of workplace partnership?' Employee Relations, 27(3): 289-307.

Dobbins, A. and Gunnigle, P. (2009), 'Can voluntary workplace partnership deliver sustainable mutual gains?', British Journal of Industrial Relations, 47(3): 546-570.

Doucouliagos, C. and Laroche, P. (2003), 'What Do Unions Do to Productivity? A Meta-Analysis.' Industrial Relations, 42(4): 650-691.

Dundon, T., Wilkinson, A., Marchington, M. and Ackers, P. (2005), 'The management of voice in non-union organisations: managers' perspectives', Employee Relations, 27(3): 307-320.

Evans, C., Harvey, G., and Turnbull, P. (2012), 'When partnerships don't 'match-up': an evaluation of labour-management partnerships in the automotive components and civil aviation industries', Human Resource Management Journal, 22(1): 60-75.

Freeman, R. (2005). 'What Do Unions Do? The m-brane stringtwister edition.' Journal of Labour Research, 26(4): 641-668.

Freeman, R.B. and Lazear, E. (1995), 'An economic analysis of works councils', in Rogers, J. and Streeck, W. (Eds), Works Councils Consultation, Representation, and Cooperation in Industrial Relations. Chicago, IL: University of Chicago Press, 27-50.

Freeman, R. and Medoff, J. (1984). What Do Unions Do? New York: Basic Books. 
Gold, M. (2010), 'Employee participation in the EU: The long and winding road to legislation', Economic and Industrial Democracy, 31(4): 9-23.

Glover L., Tregaskis, O. and Butler, P. (2014), 'Mutual gains? The Workers' Verdict: A Longitudinal Study, International Journal of Human Resource Management (insert issue details)

Greenwald, R. A. (2004), 'Working the docks: Labor, management and the new waterfront', Review of Business, 25(3): 16-22.

Guest, D. (2011), 'Human resource management and performance: still searching for some answers,' Human Resource Management Journal, 21(1): 3-13.

Guest, D. and Peccei, R. (2001), 'Partnership at Work: mutuality and the balance of advantage' British Journal of Industrial Relations, 39(2): 207-236.

Hall, M., and Purcell, J. (2012). Consultation at work: regulation and practice. Oxford: Oxford University Press.

Heery, E. (2002), 'Partnership versus Organising: Alternative Futures for British Trade Unionism', Industrial Relations Journal, 33(1): 20-35.

Hirsch, B. T. (2004), 'What do unions do for economic performance?', Journal of Labor Research, 25(3): 415-455.

Holland, P., Cooper, BK., Pyman A. and Teicher, J. (2012), 'Trust in management: the role of employee voice arrangements and perceived managerial opposition to unions', Human Resource Management Journal, 22(4): 377-91.

Hyman, R. (2002), 'The future of unions', Just Labour, 1(1): 7-15.

IPA (1997). Towards Industrial Partnership: A New Approach to Relationships at Work, London: Involvement and Partnership Association.

Jenkins, J. (2008), 'Pressurised partnership: a case of perishable compromise in contested terrain', New Technology, Work and Employment, 23(3): 167-180.

Johnstone, S., Wilkinson, A. and Ackers, P. (2009), 'The British Partnership Phenomenon', Human Resource Management Journal, 16(3): 260-279.

Johnstone, S., Ackers, P., and Wilkinson, A. (2010), 'Better than nothing? Is non-union partnership a contradiction in terms?', Journal of Industrial Relations, 52(2): 151-168.

Johnstone, S. and Wilkinson, A. (2013), 'Employee voice and partnership', in G. Saridakis and C. Cooper (Eds), How HR can Drive Growth. London: Elgar.

Kaufman, B., and Taras, D. (2010), 'Employee participation through non-union forms of employee representation', in A. Wilkinson, P. J. Gollan, M. Marchington and D. Lewin (Eds.) The Oxford Handbook of Participation in Organisations. New York: Oxford University Press: 258-285.

Kelly, J. (1999), 'Social partnership in Britain: Good for profits, bad for jobs and unions', Communist Review, 30(1):

Kelly, J. (2004), 'Social partnership agreements in Britain', Industrial Relations, 43(1): 267-292.

Kinge. J (2014), 'Testing Times: The development and sustainability of partnership relationships Dataset', International Journal of Human Resource Management (insert issue details)

Knies, E. and Leisink, P. (2013), 'Linking people management and extra-role behaviour: results of a longitudinal study, Human Resource Management Journal, on-line early: DOI: 10.1111/1748-8583.12023. 
Kochan, T. A., and Osterman, P. (1994). The mutual gains enterprise: Forging a winning partnership among labor, management, and government. Harvard Business Press.

Kochan, T. A., and Rubinstein, S. A. (2000). 'Toward a stakeholder theory of the firm: The Saturn partnership', Organization Science, 11(4): 367-386.

Krats, P. and Brown, TC. (2012), 'Unionised employee's reactions to the introduction of a goalbased performance appraisal system, Human Resource Management Journal, on-line early: DOI: $10.1111 / \mathrm{j} .1748-8583.2012 .00205 . x$.

McDonough, T. and Dundon, T. (2010), 'Thatcherism delayed? The Irish crisis and the paradox of social partnership', Industrial Relations Journal, 41(6): 544-562.

McIlroy, J. (2008), 'Ten years of New Labour: workplace learning, social partnership and union revitalization in Britain'. British Journal of Industrial Relations, 46(2): 283-313.

Marchington. M., and Suter, J. (2013), 'Where Informality Really Matters: Patterns of voice in a non-union firm', Industrial Relations, 52(s1): 284-313.

Marks, A., Findlay, P., Hine, J., Thompson, P., and McKinlay, A. (1998). 'The politics of partnership? Innovation in employment relations in the Scottish spirits industry'. British Journal of Industrial Relations, 36(2): 209-226.

Martinez-Lucio, M., Stuart, M. (2002), 'Assessing partnership: the prospects for, and challenges of, modernisation', Employee Relations, 24(3): 252-261

Osterman, P., Kochan, T. A., Locke, R. M., \& Piore, M. J. (2002). Working in America: A blueprint for the new labor market. MIT Press Books.

Price, R., Bailey, J. and Pyman, A. (2014), 'Varieties of Collaboration: The case of an Australian retail union', International Journal of Human Resource Management (insert issue details)

Rittau, Y., and Dundon, T. (2009), 'The roles and functions of shop stewards in workplace partnership: evidence from the Republic of Ireland', Employee Relations, 32(1): 10-27.

Roche WK. Geary J. (2006), Partnership at Work: The Quest for Radical Organisational Change. London: Routledge.

Roche WK. and Teague, P. (2014), 'Successful but Unappealing: Fifteen Years of Workplace Partnership in Ireland, International Journal of Human Resource Management (insert issue details).

Samuel, P. (2007), 'Partnership consultation and employer domination in two British life and pensions firms', Work, Employment and Society, 21(3): 459-477.

Sayce, S., Weststar, J. and Verma, A. (2012), 'The recruitment and selection of pension trustees: an integrative approach, Human Resource Management Journal, on-line early: DOI: 10.1111/1748-8583.12012.

Stuart, M., and Martinez-Lucio, M. (2000), 'Renewing the model employer: Changing employment relations and "partnership" in the health and private sectors', Journal of Management in Medicine, 14(5/6): 310-326.

Stuart, M. and Martinez-Lucio, M. (2004), Partnership and the Modernisation of Employment Relations. London: Routledge.

Teague, P. (2005), 'What is enterprise partnership?' Organization,12(4): 567-589.

Teague, P. and Donaghey, J. (2009), 'Why has Irish social partnership survived?', British Journal of Industrial Relations, 47(1): 55-78.

Teague, P., and Hann, D. (2010), 'Problems with partnership at work: lessons from an Irish case study', Human Resource Management Journal, 20(1): 100-114. 
Teague, P. and Roche, WK. (2013), 'Recessionary bundles: HR practices in the Irish economic crisis', Human Resource Management Journal, on-line early: DOI: 10.1111/17488583.12019.

Terry, M. (2003a), 'Can “partnership" reverse the decline of British trade unions?', Work, Employment and Society, 17(3):459-472.

Terry, M. (2003b), 'Partnership and the future of trade unions in the UK', Economic and Industrial Democracy, 24(4): 485-507.

Townsend, K., Wilkinson, A., Burgess, J., and Brown, K., (2013), 'Has Australia's Road to Workplace Partnership Reached a Dead End?', International Journal of Comparative Labour Law and Industrial Relations (forthcoming).

Townsend, K., Wilkinson, A., and Burgess, J. (2014), 'Routes to partial success: collaborative employment relations and employee engagement', International Journal of Human Resource Management, (insert issue details)

TUC (1999), Partners for Progress, London: Trades Union Congress.

Turnbull, P., Blyton, P., and Harvey, G. (2004), 'Cleared for take-off? Management-labour partnership in the European civil aviation industry', European Journal of Industrial Relations, 10(3): 287-307.

Walton, R. E., and McKersie, R. B. (1965). A behavioral theory of labor negotiations: An analysis of a social interaction system. Ithaca: ILR Press.

Watling, D., Snook, J. (2001), 'Works councils and trade unions: complementary or competitive? The case of SAGCo', paper presented at the BUIRA Conference, Manchester Metropolitan University, Manchester, 5-7 July.

Whyman, P. and Petrescu, A. (2014), 'Partnership, Flexible Working Practices and the Realisation of Mutual Gains: Evidence from the British WERS 2004 Dataset', International Journal of Human Resource Management, (insert issue details)

Wilkinson, A., Dundon, T. and Grugulis, I. (2007), 'Information but not consultation: exploring employee involvement in SMEs', International Journal of Human Resource Management, 18(7): 1279-1297.

Wilkinson, A., Godfrey, G. and Marchington, M. (1997), 'Bouquets, brickbats and blinkers: TQM and employee involvement in context', Organisation Studies, 18 (5): 799-82.

Wilkinson, A, Gollan, P, Marchington, M and Lewin, D. (2010), 'Conceptualising Employee Participation in Organisations', in A Wilkinson et al (Eds), The Oxford Handbook of Participation in Organizations, Oxford University Press, Oxford: 1-25.

Wilkinson, A, Dundon, T, and Marchington, M. ( 2013), 'Employee Involvement and Voice', in Bach, S and Edwards M (Eds) Managing Human Resources, Oxford: Blackwell.

Wilkinson A, Dundon T. Donaghey J and Freeman, R. (2014), The Handbook of Employee Voice, London: Elgar (forthcoming)

Wood, G. (2010), 'Employee participation in developing and emerging countries', in A. Wilkinson, P. J. Gollan, M. Marchington and D. Lewin (Eds.) The Oxford Handbook of Participation in Organisations. New York: Oxford University Press. 